\title{
Artist Photovoltaic Modules
}

\author{
Shui-Yang Lien \\ Department of Materials Science and Engineering, Da-Yeh University, Changhua 51591, Taiwan; \\ syl@mail.dyu.edu.tw; Tel.: +886-04-851-1888 (ext. 1760)
}

Academic Editor: Narottam Das

Received: 23 May 2016; Accepted: 11 July 2016; Published: 15 July 2016

\begin{abstract}
In this paper, a full-color photovoltaic (PV) module, called the artist PV module, is developed by laser processes. A full-color image source is printed on the back of a protective glass using an inkjet printer, and a brightened grayscale mask is used to precisely define regions on the module where colors need to be revealed. Artist PV modules with $1.1 \times 1.4 \mathrm{~m}^{2}$ area have high a retaining power output of $139 \mathrm{~W}$ and an aesthetic appearance making them more competitive than other building-integrated photovoltaic (BIPV) products. Furthermore, the installation of artist PV modules as curtain walls without metal frames is also demonstrated. This type of installation offers an aesthetic advantage by introducing supporting fittings, originating from the field of glass technology. Hence, this paper is expected to elevate BIPV modules to an art form and generate research interests in developing more functional PV modules.
\end{abstract}

Keywords: building-integrated photovoltaic (BIPV); full-color; laser process; photovoltaic (PV) module

\section{Introduction}

Building-integrated photovoltaics (BIPVs) have attracted increasing attention in recent years because of their efficient use of space and effective energy production $[1,2]$. Conventional silicon wafer-based solar cells have high optoelectronic conversion efficiency, but can only be integrated on rooftops because of limitations brought about by their opaque appearance. The development of semi-transparent, thin-film amorphous silicon (a-Si) or microcrystalline silicon ( $\mu \mathrm{c}-\mathrm{Si}$ ) solar cells expands the applications of solar cells to glass-related technologies and products such as windows [3-6], skylights [7-9], and other areas that require transparency and electricity generation. Modules with $10 \%-50 \%$ transmittance are commercially available, and are fabricated through the ablation of films on the modules [10-14]. However, BIPVs have a small market share nowadays, mainly because of limited aesthetic choices. One survey shows that more than $85 \%$ of architects believe that aesthetic concerns increase photovoltaic (PV) system installations even with reduced conversion efficiencies [15]. Access to efficient PV modules with a variety of colors is highly desirable to further increase user acceptance and the installation rate. Existing literatures [16-19] proposed several approaches for fabricating colored Si-based PV modules, but these modules can only display a single color, and thus give a dull appearance.

To overcome challenges of color presentation, we have developed artist PV modules, which are colorful and semi-transparent. The key features of the modules are the provision of a color image source by a back protective glass, and color visualization by using laser processes with a brightened grayscale mask. In this paper, the structures of artist PV modules and the related laser scribing mechanism are first described. Effects of the mask on solar cell conversion efficiency are investigated. Furthermore, characteristics of a scaled, full-color a-Si/ $\mu \mathrm{c}-\mathrm{Si}$ tandem PV module are presented for comparison with commercial Si-based thin-film BIPV products. Finally, practical applications and installation details of the PV modules as curtain walls are discussed. 


\section{Experimental Methods}

\subsection{Fabrication of Artist Photovoltaic Modules}

The schematic structure of artist PV modules is shown in Figure 1a. The module consists of a PV submodule at the front and a protective glass at the back. The fabrication process was described below. The submodule was series-connected by standards P1 to P3 laser processes [20]. Then a custom image was ink-jet-printed on the back glass in full color, and printed on a transparent sticker with adjustments, as shown in Figure $1 \mathrm{~b}$. The image was converted to grayscale (from $\mathrm{A}$ to $\mathrm{A}^{\prime}$ ) according to the luminosity method formula [21]:

$$
\text { Gray }=0.21 \mathrm{R}+0.71 \mathrm{G}+0.07 \mathrm{~B}
$$

where R, G, and B are the intensities of the red, green, and blue colors of the pixel, respectively. The percentage values indicated on the grayscale image were the transmittance $T_{\mathrm{m}}$. Afterwards, the brightness of the grayscale image was increased by $40 \%$ or above (from $\mathrm{A}^{\prime}$ to $\mathrm{A}^{\prime \prime}$ ). The transparent sticker with the brightened grayscale image was stuck on the glass side of the submodule as a mask for the subsequent $532 \mathrm{~nm}$ laser process (herein denoted as P4 laser scribing), which scanned line-by-line over the submodule. The spacing of the laser line was about $0.4 \mathrm{~mm}$. It should be noted that if the mask was only converted to grayscale but not brightened, many color pixels would change to heavy gray. The resultant patterned image on the submodule would be also grayscale, but when it encapsulated with the back glass, the full-color image on the latter could hardly be observable from the submodule side. The brightening allowed the P4 laser to remove the regions on the submodule where the colors need to be revealed, so the image could be seen from the both sides of the module. All the laser processes were performed through the glass side of the submodule, and the detailed laser parameters are summarized in Table 1. Finally, the scribed submodule was encapsulated with the back glass in ethylene vinyl acetate (EVA) to finish the fabrication of the artist PV module. In addition, the ink on the back glass was ultraviolet (UV)-resistant to inhibit fade and discoloration. The durability of the inks was more than 10 years.

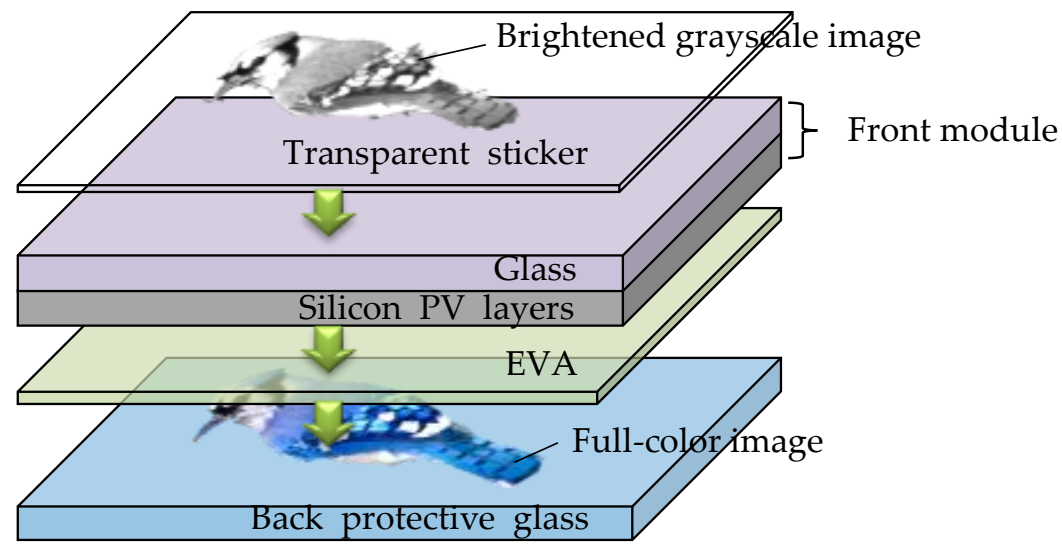

(a)

Figure 1. Cont. 


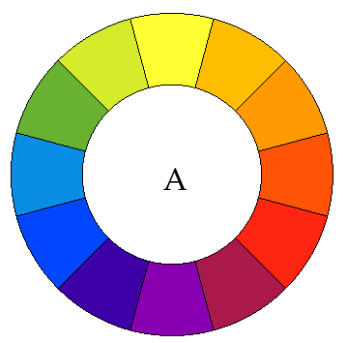

Image source

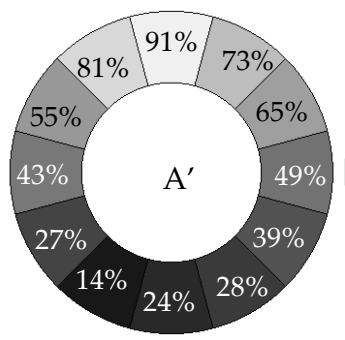

Grayscale

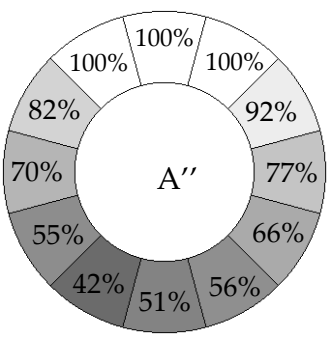

Brightened grayscale

(b)

Figure 1. (a) The schematic structure of the full-color artist photovoltaic (PV) modules; and (b) a comparison of the masks in our previous work (gray scale) and the present work (brightened gray scale). The indicated percentage values are the gray transmittance of the corresponding pixels.

Table 1. Laser parameters used for P1, P2, P3 and P4 processes.

\begin{tabular}{ccccc}
\hline Parameter & P1 & P2 & P3 & P4 \\
\hline Wavelength $(\mathrm{nm})$ & 1064 & 532 & 532 & 532 \\
Focal length $(\mathrm{mm})$ & 18 & 27 & 27 & 37 \\
Power $(\mathrm{W})$ & 5 & 0.25 & 0.35 & 0.6 \\
Line width $(\mu \mathrm{m})$ & 30 & 29.8 & 42 & 40 \\
Velocity $(\mathrm{mm} / \mathrm{s})$ & 350 & 400 & 325 & 400 \\
Pulse frequency $(\mathrm{Hz})$ & 20 & 16 & 12 & 18 \\
\hline
\end{tabular}

As the mask image might consist of various pixels with different $T_{\mathrm{m}}$ after being converted to brightened grayscale, individual investigation for each pixel is essential to clarify their impacts on the submodules. Five submodules $\left(5 \mathrm{~cm} \times 5 \mathrm{~cm}\right.$ ) and masks with $T_{\mathrm{m}}=20 \%, 40 \%, 60 \%, 80 \%$ and $100 \%$ were prepared. Mask transmittance was confirmed by UV-visible spectroscopy (Titan Electro-Optics Co. Ltd., Taipei, Taiwan) at a wavelength of $532 \mathrm{~nm}$ with an error of less than 5\% as shown in Figure 2. The morphology of the submodules was observed through scanning electron microscope (SEM) and optical microscope (OM) (M\&T Optics Co. Ltd., Taipei, Taiwan). The depth profiles of the scribes were obtained using an alpha profilometer (KTA Tencor, Milpitas, CA, USA). The laser scribe width was evaluated by the full-width at half maximum value of the scribe. The current-voltage $(I-V)$ characteristics of the modules were measured at AM1.5G $\left(1000 \mathrm{~W} / \mathrm{m}^{2}\right)$ using a solar simulator. The stabilized power output of the PV modules was determined by a standard light soaking test according to IEC 61646 [22] at $60{ }^{\circ} \mathrm{C}$ for $1000 \mathrm{~h}$.

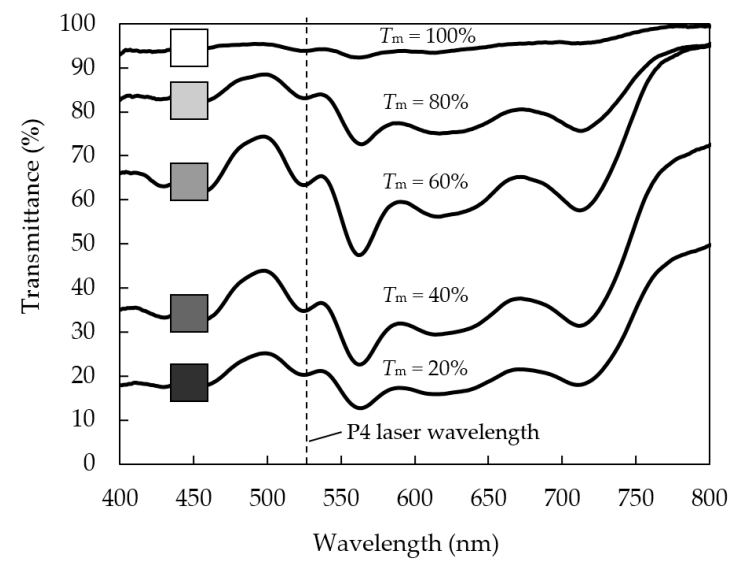

Figure 2. Transmittance spectra of the masks with $T_{\mathrm{m}}=20 \%, 40 \%, 60 \%, 80 \%$, and $100 \%$. 


\subsection{Mechenism of P4 Laser-Scribing Process for Image Patterning}

The mechanism of P4 scribing is based on the laser energy intensity of the Gaussian distribution [23] and Beer's law [11]:

$$
\begin{gathered}
I=T_{\mathrm{m}} \alpha \frac{P}{2 \pi R_{0}^{2}} \mathrm{e}^{\left(-\frac{x^{2}}{2 R_{0}}\right)} \\
d=\frac{-1}{\alpha} \ln \left(\frac{I_{\text {th }}}{I}\right), \text { for } I>I_{\text {th }}
\end{gathered}
$$

where $I$ is the laser energy intensity after passing the mask, $\alpha$ is the absorptivity, $P$ is the laser power, $R_{0}$ is the laser spot radius, $x$ is the distance across scribes, $I_{\text {th }}$ is the ablation threshold intensity of silicon films, and $d$ is the scribe depth. The grayscale mask will decrease laser intensity depending on $T_{\mathrm{m}}$, thereby leading to various scribing depths, as schemed in Figure 3. We applied this concept to pattern the image from the mask to the PV module.

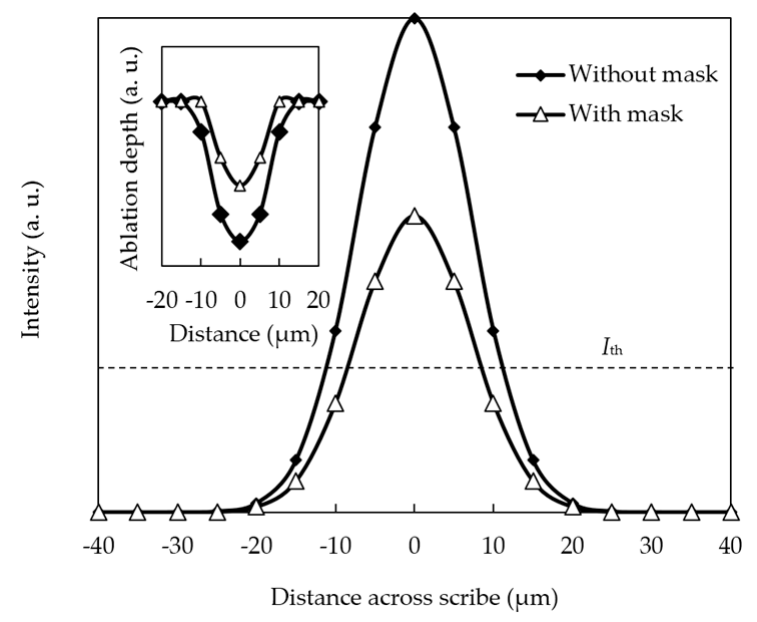

Figure 3. Theoretical calculation results of laser intensity and ablation depth distribution across the scribes for submodules with and without mask.

\section{Results and Discussion}

The OM and SEM topological images, as well as the depth profiles, of the scribes for mask transmittances $\left(T_{\mathrm{m}}\right)$ of $100 \%, 80 \%, 60 \%, 40 \%$, and $20 \%$ are shown in Figure 4 . The case of $T_{\mathrm{m}}=100 \%$ shows round laser spots (Figure 4a1,a2,b1,b2) and straight side walls on the scribes (Figure 4a3,b3). This result indicates that laser intensity is not significantly affected by the mask. As $T_{m}$ decreases, film delamination and spot-size distortion occur at the edges of the scribes (Figure $4 \mathrm{~d} 1$, d2,e1,e2). The shape of the scribe changes from $U$ to $V$ as the depth and width decrease. $T_{\mathrm{m}}$ below $20 \%$ did not lead to film ablation. This phenomenon can be explained by the fact that after passing the mask, the laser intensity value was lower than the a-Si threshold ablation, typically $0.4 \mathrm{~J} / \mathrm{cm}^{2}$ [24]. From these results, masks with high $T_{\mathrm{m}}$ lead to fewer deviations from optimal laser conditions, thus having lower electrical loss [23]. However, the use of high $T_{\mathrm{m}}$ masks results in the increased removal of films in the effective area of the modules. These two factors are the trade-offs in determining the final device performance. 


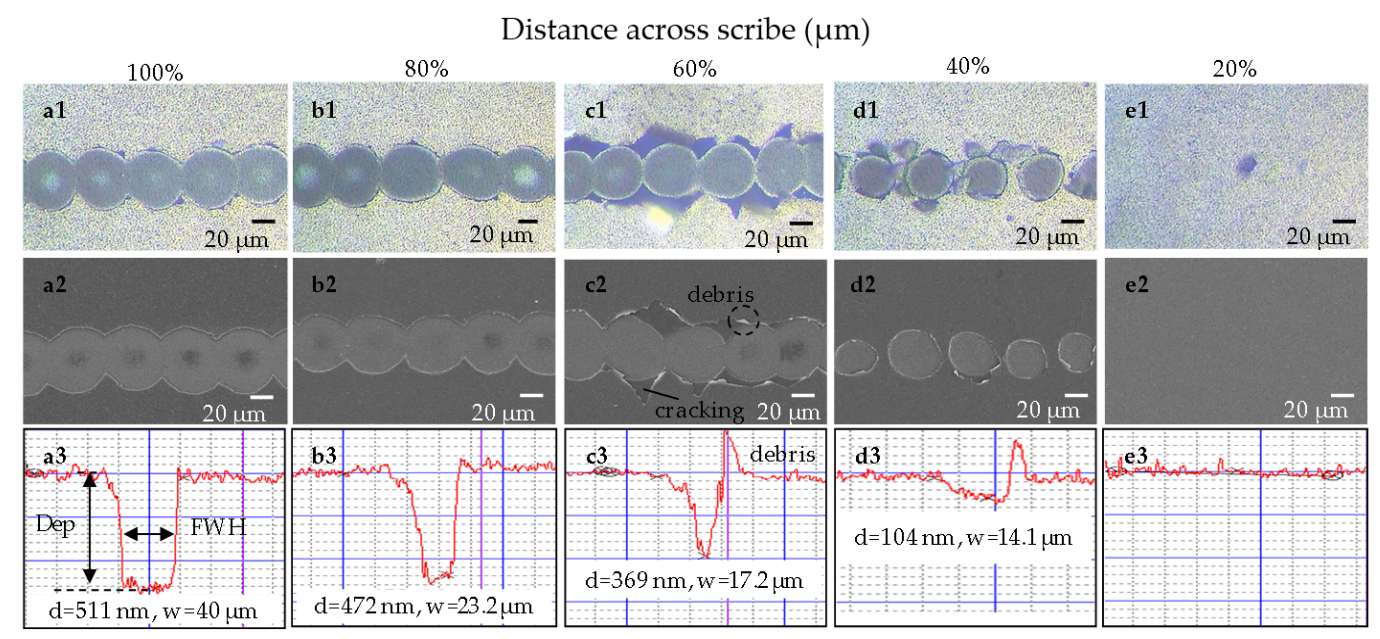

Figure 4. The optical microscope (OM) (top) and scanning electron microscope (SEM) (middle) images, and depth profiles (bottom) for $T_{\mathrm{m}}=20 \%, 40 \%, 60 \%, 80 \%$ and $100 \%$ of a-Si PV modules.

The effects of the mask on the a-Si submodule performance such as short-circuit current density $\left(J_{\mathrm{sc}}\right)$, open-circuit voltage $\left(V_{\mathrm{oc}}\right)$, fill factor $(F F)$, and conversion efficiency $(\eta)$ are shown in Figure 5 a. The original submodule (without the $\mathrm{P} 4$ process) is also indicated as a reference for comparing power reduction values. It can be seen that $J_{\mathrm{sc}}$ almost remains unchanged when $T_{\mathrm{m}}$ increases from $0 \%$ to $20 \%$, and decreases from $2.45 \mathrm{~mA} / \mathrm{cm}^{2}$ to $2.1 \mathrm{~mA} / \mathrm{cm}^{2}$ with the increase of $T_{\mathrm{m}}$ from $20 \%$ to $100 \%$. The reduction in $J_{\mathrm{sc}}$ is attributed to optical loss caused by the ablation of the active layers. $V_{\mathrm{oc}}$ and $F F$ show similar trends. $T_{\mathrm{m}}=40 \%$ and $60 \%$ have lower values as a consequence of the deteriorating surface states. The resulting $\eta$ value is the lowest for $T_{\mathrm{m}}=100 \%$. Therefore, although grayscale design may lead to a reduction in $V_{\mathrm{oc}}$ and $F F$, the module still has higher performance than $T_{\mathrm{m}}=100 \%$. These results are still validated in the case of a-Si/ $\mu \mathrm{c}-\mathrm{Si}$ tandem solar cells (Figure $5 \mathrm{~b}$ ). It should be noted that a module with $T_{\mathrm{m}}=100 \%$ can be analogized to the $10 \%$ semi-transparent module, while the artist module is a combination of $T_{\mathrm{m}}=0 \%-100 \%$. The latter could be assumed to have higher, or at least equal, performance than the $10 \%$ semi-transparent module.

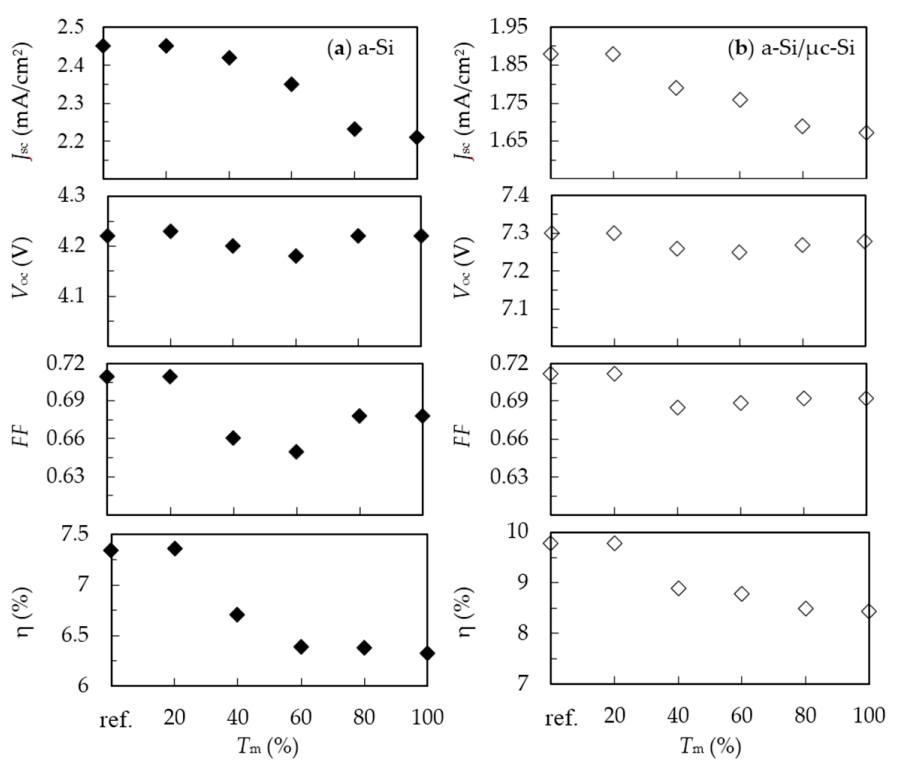

Figure 5. External parameters of (a) a-Si and (b) a-Si / $\mu c-S i$ submodules with different $T_{\mathrm{m}}$ values. The denoted reference is the submodule without the P4 laser process. 


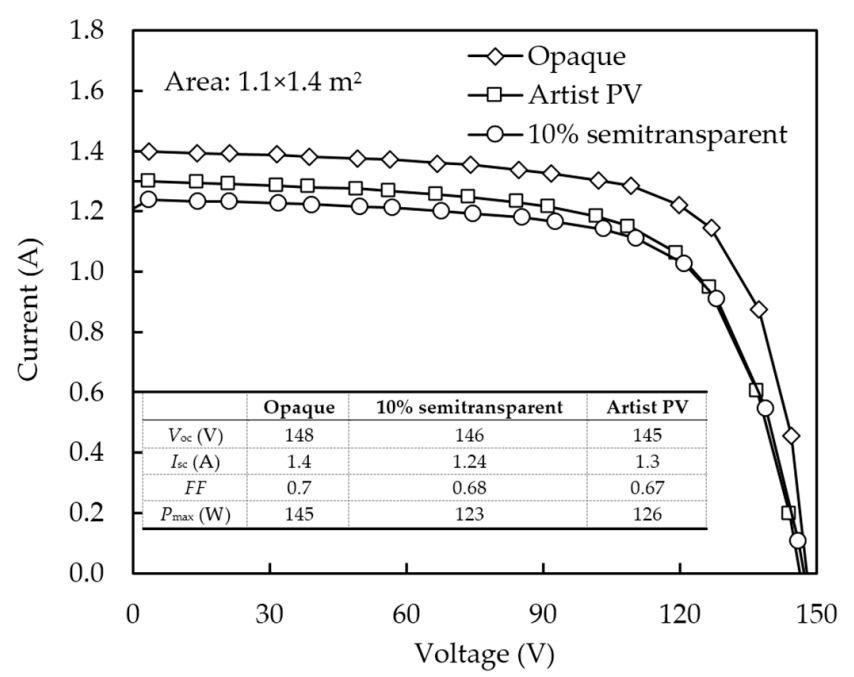

Figure 6. Current-voltage $(I-V)$ characteristics of opaque, $10 \%$ semi-transparent and artist a-Si/ $\mu \mathrm{c}$ PV modules.

A fifth generation-sized $\left(1.1 \times 1.4 \mathrm{~m}^{2}\right)$ artist a-Si/ $\mu \mathrm{c}-\mathrm{Si} \mathrm{PV}$ module is fabricated, and its $I-V$ characteristics are compared to that of the opaque and 10\% semi-transparent modules as shown in Figure 6. Each of the PV modules was fabricated under identical laser conditions. The result matches Figure 5, which confirms the expectation that the full-color module is more competitive than the $10 \%$ semi-transparent PV module. A stable power output of $126 \mathrm{~W}$ (14.2\% reduction) of the artist PV module is achieved, while the $10 \%$ semi-transparent module shows a $123 \mathrm{~W}(16.3 \%$ reduction) stabilized power output. We further increase the performance from $126 \mathrm{~W}$ to $139 \mathrm{~W}$ for the artist module and $123-134 \mathrm{~W}$ for the $10 \%$ semi-transparent module when using a higher performance of $160 \mathrm{~W}$ of the opaque submodules (NexPower Tech. Corp., Taichung, Taiwan).

The $160 \mathrm{~W}$ opaque, $134 \mathrm{~W} 10 \%$ semi-transparent and $139 \mathrm{~W}$ artist PV modules were installed with different orientations and tilt angles with respect to the ground in Changhua, Taiwan, for one year from 2014. The modules were placed outside and connected with a maximum power point tracking inverter that recorded the power output. The irradiance was measured by an optical power meter. The weather condition was changeable, but the total irradiance was about equal to 1299.4 peak sun hours (average $3.56 \mathrm{~h} /$ day). Figure 7 shows the annual power generation for the three modules; the capacity of each module is normalized to $1 \mathrm{~kW}$. In all the cases the annual power generation is the highest for the opaque PV module and the lowest for the 10\% semi-transparent module. Despite having the same installation capacity, the three types of modules have different annual power generation due to different performance under variable illumination irradiances over a day. Particularly for weak light illumination $\left(\leqslant 200 \mathrm{~W} / \mathrm{m}^{2}\right)$, the module performance depends on the shunt resistance [25], which can be calculated as the inverse slope at the point of $V=0$ in the $I-V$ curve. The calculated shunt resistances for the opaque, artist $\mathrm{PV}$, and the $10 \%$ transmittance modules are 4139,3468 , and $3003 \Omega$, respectively. Compared to the $10 \%$ semi-transparent modules, artist PV modules have a smaller laser ablation area and therefore higher shunt resistance. The non-tilted modules show a power generation of around 1354,1288 and $1185 \mathrm{~kW}$ for opaque, artist $\mathrm{PV}$, and $10 \%$ semi-transparent modules, respectively. The $23.5^{\circ}$-tilted modules show about $4 \%-5 \%$ reduction in power generation, except for the modules facing south, showing even higher performance than non-tilted ones. This can be related to improvement in plane-of-array irradiance. A significant reduction in power generation is observed for the $90^{\circ}$-tilted modules. Power generations of $600-800 \mathrm{~W}$, approximately half of that of $0^{\circ}$ - and $23.5^{\circ}$-tilted modules, are obtained. 


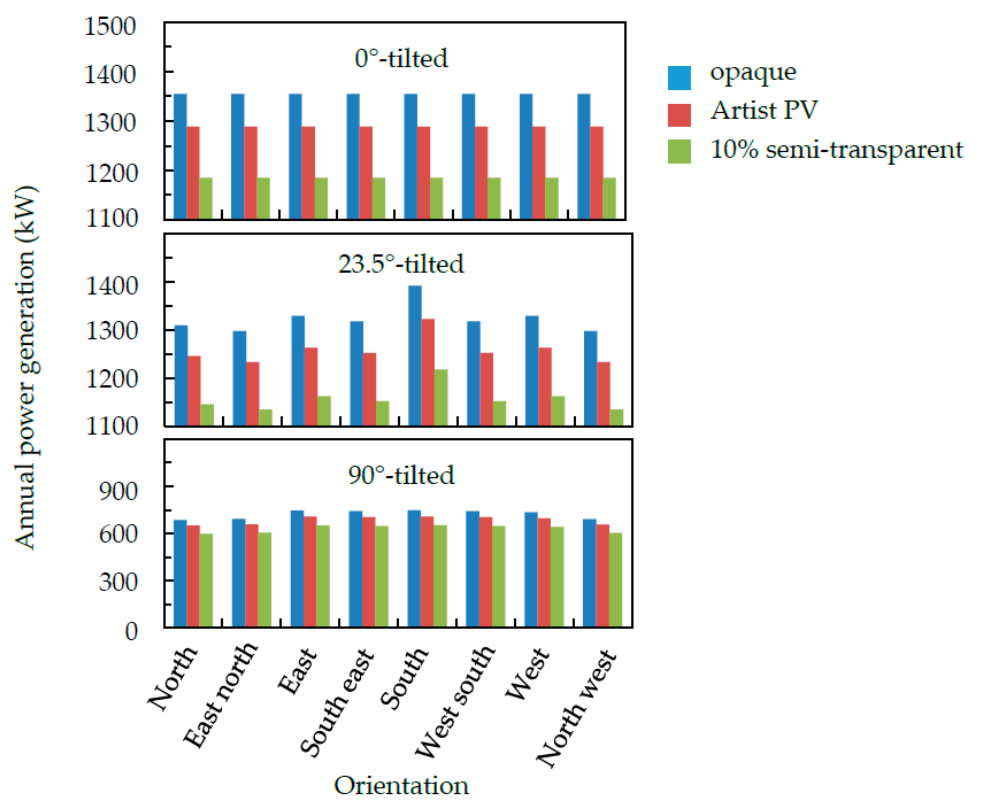

Figure 7. Annual power generation of opaque, 10\% semi-transparent and artist PV modules installed with different tilt angles and orientations. The PV modules are installed in Changhua, Taiwan.

Figure 8 demonstrates the installation of the artist PV modules, wherein four modules are supported tightly by glass fittings at the corners of each module. The modules are tilted approximately $90^{\circ}$ to the horizontal. This installation method has been widely used in traditional glass curtain walls, and is engineered for safety and strength without the need of metal frames (which can block the view) to offer visual beauty.

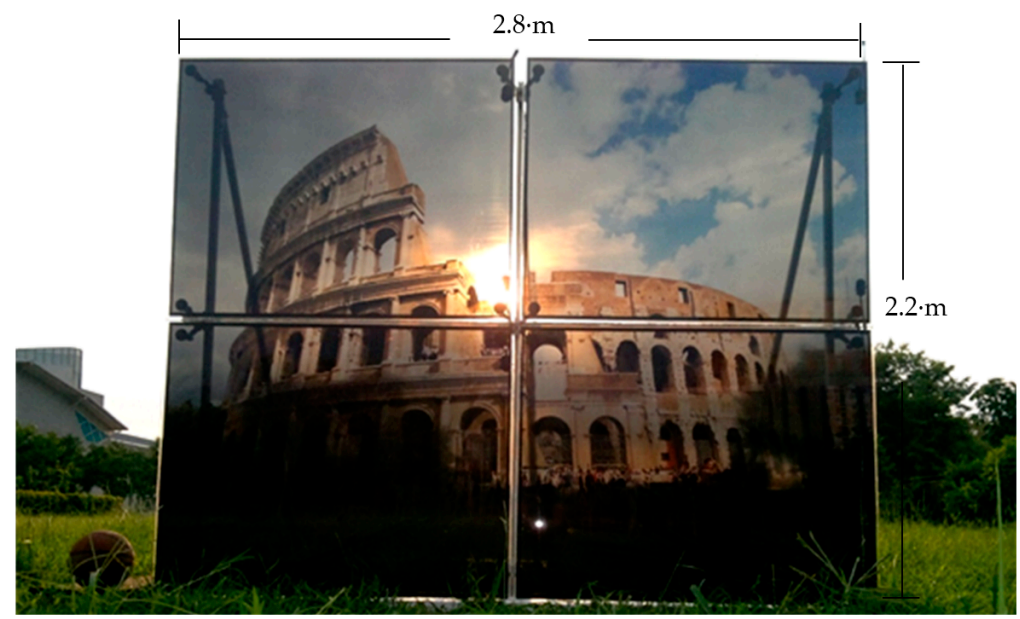

Figure 8. Annual power generation of opaque, $10 \%$ semi-transparent and artist PV modules installed with different tilt angles and orientations. The PV modules are installed in Changhua, Taiwan.

We introduce this method from the field of glass to BIPV technology while solving certain problems described as follows. Figure 9a shows the glass fittings installed in traditional glasses and BIPV modules. The most cost-effective method for glass fittings is to drill holes from the back to the front, and then to use screws (Figure 9b). However, this is not suitable for BIPV modules as the holes drilled on the PV modules can deteriorate performances, and the holes expose the module to a high risk of water leakage. Hence, we only drilled holes on the corners of the back glass, and inserted alternative routels into the holes (Figure 9c). The back glass was then EVA-laminated with 
the PV modules. The EVA would penetrate the back glass through the holes to fix the routels after encapsulation. This method prevents module damage and water leakage. Finally, PV curtain walls with high aesthetic quality can be built.

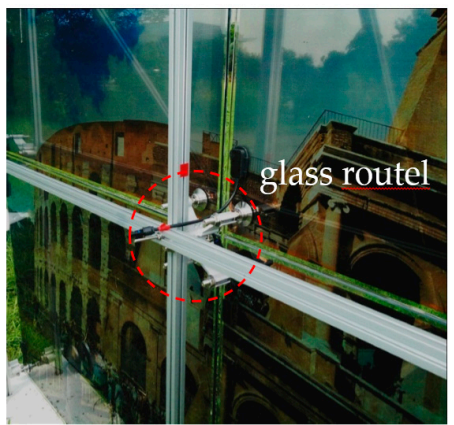

(a)

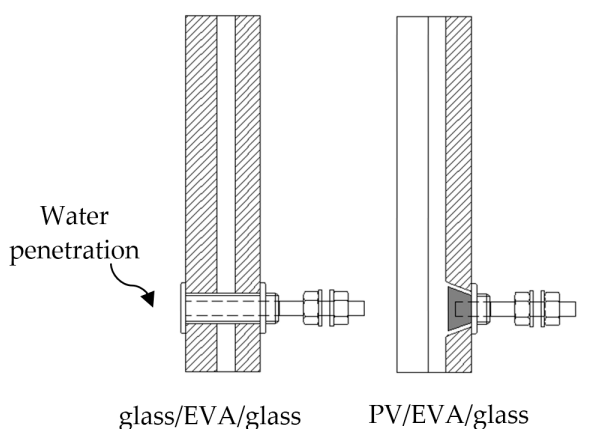

(b)

(c)

Figure 9. (a) Installation of artist PV modules with glass routels, and a comparison of the routels used in (b) traditional glass; and (c) artist PV modules. EVA: ethylene vinyl acetate.

\section{Conclusions}

We have demonstrated a full-color, semi-transparent artist PV module using laser processes with a brightened grayscale mask that precisely defines the regions that need to be removed or retained. This work can be regarded as an evolution of BIPV module designs from plain and simple to extremely aesthetic. Furthermore, the high retaining power output of $139 \mathrm{~W}$ makes the full-color module more competitive than other commercial semi-transparent modules. This technique is expected to break the stereotype that solar cells are only for power generation, and can possibly elevate PV products into an art form.

Acknowledgments: This work is sponsored by the Ministry of Science and Technology of the Republic of China under Contract Nos. 104-2221-E-212-002-MY3 and 104-2632-E-212-002.

Conflicts of Interest: The authors declare no conflict of interest.

\section{References}

1. Fung, T.Y.Y.; Yang, H. Study on thermal performance of semi-transparent building-integrated photovoltaic glazings. Energy Build. 2008, 40, 341-350. [CrossRef]

2. James, P.A.B.; Jentsch, M.F.; Bahaj, A.S. Quantifying the added value of BiPV as a shading solution in atria. Sol. Energy 2009, 83, 220-231. [CrossRef]

3. Miyazaki, T.; Akisawa, A.; Kashiwagi, T. Energy savings of office buildings by the use of semi-transparent solar cells for windows. Renew. Energy 2005, 30, 281-304. [CrossRef]

4. Yoon, J.H.; Song, J.; Lee, S.J. Practical application of building integrated photovoltaic (BIPV) system using transparent amorphous silicon thin-film PV module. Sol. Energy 2011, 85, 723-733. [CrossRef]

5. Chow, T.T.; Fong, K.F.; He, W.; Lin, Z.; Chan, A.L.S. Performance evaluation of a PV ventilated window applying to office building of Hong Kong. Energy Build. 2007, 39, 643-650. [CrossRef]

6. Chow, T.T.; Qiu, Z.; Li, C. Potential application of "see-through" solar cells in ventilated glazing in Hong Kong. Sol. Energy Mater. Sol. Cells 2009, 93, 230-238. [CrossRef]

7. Dabbour, M.; Arafa, S. Silicone glazing for solar applications in rural areas. Renew. Energy 1993, 3, $245-248$. [CrossRef]

8. Chehab, O. The intelligent façade photovoltaic and architecture. Renew. Energy 1994, 5, 188-204. [CrossRef]

9. Sick, F.; Erge, T. Photovoltaics in Buildings: A Handbook for Architects and Engineers; Earthscan Publications Ltd.: London, UK, 1996; pp. 95-105. 
10. Takeoka, A.; Kouzuma, S.; Tanaka, H.; Inoue, H.; Murata, K.; Morizane, M.; Nakamura, N.; Nishiwaki, H.; Ohnishi, M.; Nakano, S.; et al. Development and application of see-through a-Si solar cells. Sol. Energy Mater. Sol. Cells 1993, 29, 243-252. [CrossRef]

11. Nishiwaki, H.; Sakai, S.; Matsumi, S.; Tsuda, S.; Kiyama, S.; Yamamoto, Y.; Hosokawa, H.; Suzuki, R.; Osumi, M.; Ohnishi, M.; et al. Through-Hole Contact (THC) integrated-type a-Si solar cell submodule by a new laser photo-etching method. Sol. Energy Mater. Sol. Cells 1993, 31, 97-108. [CrossRef]

12. Tarui, H.; Tsuda, S.; Nakano, S. Recent progress of amorphous silicon solar cell applications and systems. Renew. Energy 1996, 8, 390-395. [CrossRef]

13. Nitta, Y.; Yamagishi, H.; Nomura, T.; Minabuchi, K.; Kondo, M.; Hatta, M.; Tawada, Y. New photovoltaic system exploited by the unique characteristics in thin film Si modules. In Proceedings of the 3rd World Conference on Photovoltaic Energy Conversion, Osaka, Japan, 18 May 2003; Volume 2, pp. 1903-1907.

14. Leal, V.; Maldonado, E.; Erell, E.; Etzion, Y. Modeling a reversible ventilated window for simulation within ESP-R-The SOLVENT case. In Proceedings of the 8th International Building Performance Simulation Association Conference, Eindhoven, The Netherlands, 11-14 August 2003; pp. 713-720.

15. Weiss, W.; Stadler, I. Facade integration-A new and promising opportunity for thermal solar collectors. In Proceedings of the Industry Workshop of the IEA Solar Heating and Cooling Program, Delft, The Netherlands, 2 April 2001.

16. Selj, J.H.; Mongstad, T.T.; Søndena, R.; Marstein, E.S. Reduction of optical losses in colored solar cells with multilayer antireflection coatings. Sol. Energy Mater. Sol. Cells 2011, 95, 2576-2582. [CrossRef]

17. Tsai, C.Y.; Tsai, C.Y. Development of tandem amorphous/microcrystalline silicon thin-film large-area see-through color solar panels with reflective layer and 4-step laser scribing for building-integrated photovoltaic applications. J. Nanomater. 2014, 2014. [CrossRef]

18. Myong, S.Y.; Jeon, S.W. Efficient outdoor performance of esthetic bifacial a-Si:H semi-transparent PV modules. Appl. Energy 2016, 164, 312-320. [CrossRef]

19. Perret-Aebi, L.E.; Heinstein, P.; Chapuis, V.; Schlumpf, C.; Li, H.Y.; Roecker, C.; Schueler, A.; Le Caër, V.; Joly, M.; Tween, R.; et al. Innovative solution for building integrated photovoltaics. In Proceedings of the CISBAT 2013 Cleantech for Smart Cities and Buildings, Lausanne, Switzerland, 4-6 September 2013.

20. García-Ballesteros, J.J.; Lauzurica, S.; Molpeceres, C.; Torres, I.; Canteli, D.; Gandia, J.J. Electrical losses induced by laser scribing during monolithic interconnection of devices based on a-Si:H. Phys. Procedia 2010, 5, 293-300. [CrossRef]

21. Krishna, B.C.; Bindu, V.H.; Durga, K.L.; Lokeshwar, G.; Kumar, G.A. An efficient face recognition system by declining rejection rate using PCA. Int. J. Eng. Sci. Adv. Technol. 2012, 2, 93-98.

22. Thin-Film Terrestrial Photovoltaic (PV) Modules-Design Qualification and Type Approval, 2nd ed.; 61646; International Electrotechnical Commission: Geneva, Switzerland, 2008.

23. Abderrazak, K.; Kriaa, W.; Salem, W.B.; Mhiri, H.; Lepalec, G.; Autric, M. Numerical and experimental studies of molten pool formation during an interaction of a pulse laser (Nd:YAG) with a magnesium alloy. Opt. Laser Technol. 2009, 41, 470-480. [CrossRef]

24. Luther-Davies, B.; Rode, A.V.; Madsen, N.R.; Gamaly, E.G. Picosecond high-repetition-rate pulsed laser ablation of dielectrics: The effect of energy accumulation between pulses. Opt. Eng. 2005, 44. [CrossRef]

25. Bunea, G.E.; Wilson, K.E.; Meydbray, Y.; Campbell, M.P.; Ceuster, D.M.D. Low light performance of mono-crystalline silicon solar cells. In Proceedings of the 2006 IEEE 4th World Conference on Photovoltaic Energy, Waikoloa, HI, USA, 7-12 May 2006; pp. 1312-1314.

(C) 2016 by the author; licensee MDPI, Basel, Switzerland. This article is an open access article distributed under the terms and conditions of the Creative Commons Attribution (CC-BY) license (http://creativecommons.org/licenses/by/4.0/). 